\title{
Identifying Ethical Hypernorms For Accounting Educators
}

\author{
Philip H. Siegel, McCurry and Co, CPAs, USA \\ Steven Mintz, California State Polytechnic University, USA \\ Mohsen Naser-Tavakolian, San Francisco State University, USA \\ John O'Shaughnessy, San Francisco State University, USA
}

\begin{abstract}
Accounting educators have a unique role in academe because students learn about codes of ethics that will guide their actions as professionals. We identify hypernorms related to internal auditing educators that reflect unethical behaviors believed to be universally unacceptable by that community. We then compare the results to a prior survey of accounting educators and identify ethical principles for accounting academics in their roles as teachers and researchers. The results might help to develop a code of ethics for accounting educators to help them serve as role models for students as they prepare to enter the accounting profession.
\end{abstract}

Keywords: Hypernorms; Internal Auditing

\section{INTRODUCTION}

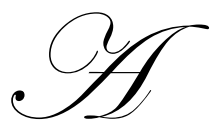

ccounting educators have a unique role to play in academe because the field of accounting, including internal auditors, teaches students about codes of ethics that will guide their actions as professionals. We identify conduct thought to be unacceptable by accounting educator groups to form a consensus about activities that might negatively affect the role model aspect of accounting educators charged with preparing students to enter the accounting profession. The purpose of this paper is to report the results of a survey of internal audit educators about certain behaviors considered to be unacceptable and compare these results with an earlier study of unacceptable behaviors of accounting educators. Hypernorms are identified if both studies indicate a type of behavior is unacceptable.

Internal audit educators were selected for the study because internal auditors provide the first line of defense against accounting fraud such as the ones that occurred at Enron and WorldCom. A strong set of ethical principles is needed to meet the responsibilities of internal auditors. Accounting educators should model certain behaviors in their research activities and in teaching to help students internalize the values of the profession. A code of ethics for accounting educators might be developed from the results of this study to provide a foundation to achieve these goals.

The paper proceeds as follows. The next section reviews the conceptual model that underlies the research study using Social Contract Theory and the identification of hypernorms. This is followed by the methodology used including analytic techniques. We then report the hypernorms identified in the survey of internal audit educators and compare them to a prior study of accounting educators. This leads to developing some principles that might provide the basis for developing a code of ethics that identifies the ethical obligations of faculty as teachers and researchers. We conclude with a discussion of limitations and areas for future research.

\section{CONCEPTUAL MODEL}

The research reported in this paper is designed to identify unethical behaviors as perceived by internal audit educators that might prevent meeting their obligations to students, in research activities, and as administrators. We compare the results to a similar survey conducted by Sirgy et al. (2005) with a target group of all accounting 
educators. Each of the two studies used surveys to elicit responses about unethical behaviors. The responses were scored and acceptability ratings were calculated. Those unethical behaviors believed to be universally accepted by both of the educator communities (accounting and internal auditing) were identified as evidence of hypernorms.

Our approach is similar to the Critical Incident Technique (CIT) discussed by Flanagan (1954). The survey instrument details a wide variety of questionable behaviors and asks respondents to identify the degree of acceptability of these behaviors. We believe that operationalizing ethics standards by applying the results of specific examples of ethical violations should be an effective way of involving various stakeholders (including faculty members) in the process of designing, enhancing, and/or implementing a code of ethics.

\section{The Social Contract}

Organizations and society coexist in a social-contractual relationship (Keeley 1988). The idea of social contracting, consisting of explicit or implicit agreements among members of society to act with reciprocal responsibility in their relationships, can be traced back to Plato. Other advocates of the social contract include philosophers Thomas Hobbes, John Locke, and Jean Jacques Rousseau. The social contract assumes a societal consensus of what is, and is not, desirable behavior by members (including corporations) of a society. According to Donaldson (1992), it not only represents an explicit set of formally specified obligations that are enforceable through legal and regulatory mechanisms, but also a set of indirect, implicit responsibilities towards those who directly or indirectly conduct business with an organization.

Social contract theory (Donaldson 1992; Donaldson \& Dunfee 1994; Donaldson \& Dunfee 1999; Dunfee 1991) argues that each community (i.e., internal auditors) has its own ethical norms. Donaldson and Dunfee (1994) indicate that business ethics and corresponding rules should be based on norms determined by local communities. Communities, therefore, determine what appropriate or inappropriate behavior is at a particular time and place. For example, a code of ethics for internal auditors and other related professionals should be based on the ethical norms of the internal auditing educator community that reflect educators' views of what is acceptable or unacceptable faculty behavior.

\section{Hypernorms}

Donaldson and Dunfee (1999) address the concept of ethical norms developed by a local community in terms of what they term "hypernorms." Hypernorms are ethical norms considered highly legitimate and obligatory. "They are second-order moral concepts because they represent norms sufficiently fundamental to serve as a source of evaluation and criticism of community-generated norms."

Our study focuses on establishing evidence for hypernorms related to internal auditing educators by identifying unethical behaviors believed to be universally unacceptable by the internal auditing educator community. A survey of internal auditing educators asking respondents to rate the degree of acceptability of a variety of questionable behaviors enables us to identify hypernorms. Thus, for the purpose of our study, we define internal audit educators' hypernorms as unethical behaviors widely regarded as unacceptable by the vast majority of internal audit educators.

Birkett (1999) studied a variety of ethics codes and points out that "codes of conduct or behavior may prescribe what will be done, and how - leaving little room for discretion; alternatively they may proscribe what may not be done, leaving a space for the exercise of discretion otherwise." We express the results in the negative because, we believe, it is more specific than to express them in the positive. For example, one hypernorm (unacceptable behavior) is "informing students they will be tested with one type of exam and then giving them another type of exam." If expressed in the positive, the hypernorm might read: Faculty should test students in a manner consistent with the way in which students were informed. 


\section{METHODOLOGY}

\section{Sampling}

An online survey was conducted in the 2008-2009 academic year directed to internal audit educators. The sampling frame involved primarily the Hasselback's 2008/09 Accounting Faculty Directory to identify internal auditing faculty. We sent questionnaires to 121 internal audit educators. Twenty-six responded to the survey. We consider this response rate to be good, especially considering the fact that the survey questionnaire was lengthy (7 pages involving 107 questions) and no incentive to complete the survey was provided.

\section{Measures and Questionnaire Design}

The questionnaire was divided into four sections following the instructions. Each section contained items reflecting specific behaviors assumed within certain roles as educators. Internal auditing educators typically play the role of teachers (Section I), researchers (Section II), administrators (Section III), and research supervisors for graduate students (Section IV). All the items in the four sections of the questionnaire were accompanied by a 5 point rating scale with a rating of one indicating that the educator believes the particular behavior to be very acceptable and a rating of five indicating that the educators believes the behavior to be very unacceptable.

We searched relevant sources from the broad literature on academic misconduct to identify specific examples of unethical educator behaviors. One central source was the discussion document of the code of ethics as proposed by Sirgy (1999) and the commentaries by Ferrell (1999), Malhotra and Miller (1999), and Kurtz (1999). A second source involved past studies. For example, we used the conceptual dimensions of unethical behaviors identified by Coe and Coe (1976), Ferrell and Skinner (1988), Mason, Bearden, and Richardson (1990), and Sherrell, Hair, and Griffin (1989). A third data source involved in-depth interviews with seven senior business educators who have conducted important research in business ethics. These interviews revealed many conceptual dimensions that enabled us to develop measures of acceptable and unacceptable behaviors. The questionnaire was pre-tested using the same seven senior business educators to ensure face validity and to eliminate redundant items. Table I shows the questionnaire and results that will be discussed later on.

The survey also contained demographic items (academic position, tenure status, doctoral degree, years of experience in academe, gender, age, employment in an institution which emphasizes research, teaching, or both, and country of the college/university). The survey questionnaire was accompanied with a cover letter signed by one of the authors underscoring the importance of this survey and its possible role in the development of a code of ethics for internal audit educators (interested parties can contact the authors for the complete questionnaire).

\section{Analytic Techniques}

Recall that the goal of this study is to identify behaviors that internal audit educators agree is clearly unacceptable (i.e., hypernorms) in their role as teachers, researchers, administrators and working with graduate students. This task can be interpreted as one of developing a valid scale of internal auditing educators' unethical behaviors and the respondents can be viewed as expert judges. In the context of assessing face validity of the scales, Hardesty and Bearden (2004) describe three effective inter-judge reliability coefficients that can be used to retain valid measures from larger pools of initial items. They are: (1) Sumscore, (2) Complete, and (3) Not Representative. The authors believe that both the Sumscore and Complete methods are more effective than the Not Representative methods.

The essence of the Complete method is to retain items that are chosen by a certain percentage of judges as completely representing unethical behaviors (Hardesty \& Bearden 2004). In our case, complete representation is indicated by a score of 4 (unacceptable) and 5 (very unacceptable). There are no consensual standards in choosing the cutoff percentage level. For example, Obermiller and Spangenberg (1998) required at least three of four judges (75 percent) to rate an item as being a very good representation of consumer skepticism toward advertising; while Saxe and Weitz (1982), Manning et al. (1995), and Sharma et al. (1990) required at least 50 percent, 60 percent, and 70 percent of their judges, respectively, to rate an item as completely representative in order to be retained. 
Consistent with Obermiller and Spangenberg (1998), Slama and Tashchian (1985), and the summative recommendation of Hardesty and Bearden (2004), we viewed 75 percent to be a reasonable level of high inter-judge reliability.

The Sumscore method considers the opinions of all judges in assigning the face validity of the items and its essence is to calculate the mean of the responses by all judges (Hardesty \& Bearden 2004). Given the nature of our study, we wanted to make sure the most representative items were retained from our initial pool of items. Therefore, both Sumscore and Complete methods were used in identifying hypernorms for internal audit educators. As to the specific cutoff mean level, no guidelines are available from the literature. We chose four as our standard because a rating of four, in our context, indicates that the behavior is considered as unacceptable.

Based on the preceding discussion, we established two standards in identifying the hypernorms (i.e., unethical behaviors) of internal audit educators: (1) a mean of 4 or above and (2) a combined frequency percentage (complete ratio) of 75 percent for judges rating a behavior as either 4 ("unacceptable") or 5 ("very unacceptable").

\section{INTERNAL AUDIT SURVEY RESULTS}

The sample involved educators with the following academic ranks: 77 percent associate and full professors and 23 percent assistant professors and instructors. The majority are tenured (73 percent), have doctoral degrees ( 92 percent), and have more than ten years of teaching experience (58 percent). A minority of respondents ( 27 percent) have more than ten years experience teaching internal auditing while the rest have an average of more than six years. The majority are male (77 percent) and 31 percent are Certified Internal Auditors.

\section{Unethical Behavior of Internal Audit Educators in their Role as Teachers} behaviors.

The following hypernorms related to internal audit educators' role as teachers reflect ethically unacceptable

- Informing students they will be tested with one type of exam and then giving them another type of exam.

- Informing students that attendance is not a factor in grades and then using attendance as a grade criterion when a student misses classes.

- Having a romantic relationship with a student in one's class.

- $\quad$ Persuading students to subscribe to trade journals and magazines when there is a personal or professional incentive for the teacher.

- $\quad$ Expecting sexual favors in return for better grades or support.

- $\quad$ Treating students in class more favorably based on their gender, religion, ethnicity, race, nationality, age, sexual orientation, or physical/mental disability.

- Treating students in class less favorably based on their gender, religion, ethnicity, race, nationality, age, sexual orientation, or physical/mental disability.

- Not providing students with a course syllabus at the beginning of the semester that spells out the nature of the course, course requirements, grading procedures, and other issues of course implementation.

- $\quad$ Disclosing students' grades with students' identity to other classmates.

- Disclosing students' grades to administrators who do not have official business with students' grades and transcripts.

- Disclosing students' grades to faculty colleagues who do not have official business with students' grades and transcripts.

- $\quad$ Disclosing students' grades to their parents without the explicit permission of the student.

- $\quad$ Not explaining to a student the reasons for receiving a certain grade.

- $\quad$ Grading students inconsistently.

- $\quad$ Failing to assume responsibility for the safety of students in the conduct of field trips and study abroad programs.

- $\quad$ Engaging in unbecoming behavior with students (e.g., drinking alcoholic beverages until feeling intoxicated). 
- $\quad$ Tell "off-color" jokes in class to liven things up and gain students' approval.

- $\quad$ Not show up repeatedly for office hours.

- $\quad$ Submitting a graduate student paper to a journal for the only purpose of getting a review and then passing on the review to the student without acknowledging the source.

- $\quad$ Exaggerating or misrepresenting a student's skills and competence in writing a letter of recommendation for the student.

- $\quad$ Not administering student evaluations because teacher anticipates negative student evaluations.

\section{Unethical Behavior of Internal Audit Educators in their Role as Researchers} researchers:

Based on the survey results, the following hypernorms were identified for internal audit educators as

- $\quad$ Expecting sexual favors in return for research credit.

- $\quad$ Giving research credit to subjects partly based on gender, religion, ethnicity, race, nationality, age, sexual orientation, or physical/mental disability.

- Not disclosing to research subjects any aspects of the study likely to cause them physical and/or psychological harm or discomfort.

- Disclosing information about research subjects-information in which subjects were assured to be treated confidentially.

- Disclosing information about the research sponsor-privileged information in which the research sponsor was assured to be treated confidentially.

- $\quad$ Not considering the safety of research subjects in the conduct of the research.

- Exaggerating and misrepresenting one's expertise and competence in a specific area of research to secure a research contract.

- $\quad$ Altering the research data to fit the researcher's theoretical notions.

- $\quad$ Altering the research data to fit the expectation of the research sponsor.

- $\quad$ Misrepresenting aspects of the research to ensure a positive peer review.

\section{Unethical Behavior of Internal Auditing Educators in their Role as Administrators} educators:

The survey results produced the following hypernorms related to the administrative role of internal audit

- Informing faculty that research and scholarship is not a factor in tenure, promotion, and merit raises but then using such criterion in performance evaluation.

- $\quad$ Expecting sexual favors from a faculty member in return for better evaluation or support.

- $\quad$ Assigning faculty to work in unsafe facilities.

- $\quad$ Failing to adhere to policies and contracts in managing faculty.

Unethical Behavior of Internal Auditing Educators in their Relationship to Graduate_Students

The survey results generated no hypernorms in this category as presented in Table 1. 


\begin{tabular}{|c|c|c|}
\hline & Mean $^{\mathbf{a}}$ & $\begin{array}{l}\text { Complete } \\
\text { Ratio }^{b}\end{array}$ \\
\hline \multicolumn{3}{|l|}{$\begin{array}{l}\text { Section I: Internal Audit Educators In Their Role As Teachers } \\
\end{array}$} \\
\hline $\begin{array}{l}\text { 1. Informing students they will be tested with one type of exam and then giving them another type of } \\
\text { exam. }\end{array}$ & 4.615 & 0.96 \\
\hline 2. Deviating significantly from the course syllabus given to students at the beginning of the semester. & 3.731 & 0.65 \\
\hline $\begin{array}{l}\text { 3. Informing students that attendance is not a factor in grades and then using attendance as a grade } \\
\text { criterion when a student misses classes. }\end{array}$ & 4.769 & 1.00 \\
\hline 4. Having a romantic relationship with a student in one's class. & 4.885 & 0.96 \\
\hline $\begin{array}{l}\text { 5. Persuading students to join professional associations when there is a personal or professional incentive } \\
\text { for the teacher. }\end{array}$ & 3.962 & 0.73 \\
\hline $\begin{array}{l}\text { 6. Persuading students to subscribe to trade journals and magazines when there is a personal or } \\
\text { professional incentive for the teacher. }\end{array}$ & 4.154 & 0.77 \\
\hline 7. Expecting sexual favors in return for better grades or support. & 5.000 & 1.00 \\
\hline $\begin{array}{l}\text { 8. Treating students in class more favorably based on their gender, religion, ethnicity, race, nationality, } \\
\text { age, sexual orientation, or physical/mental disability. }\end{array}$ & 4.840 & 1.00 \\
\hline $\begin{array}{l}\text { 9. Treating students in class less favorably based on their gender, religion, ethnicity, race, nationality, } \\
\text { age, sexual orientation, or physical/mental disability. }\end{array}$ & 4.885 & 1.00 \\
\hline $\begin{array}{l}\text { 10. Not providing students with a course syllabus at the beginning of the semester that spells out the } \\
\text { nature of the course, course requirements, grading procedures, and other issues of course implementation. }\end{array}$ & 4.240 & 0.84 \\
\hline $\begin{array}{l}\text { 11. Requiring students to purchase textbooks and other classroom materials that are costly and } \\
\text { unaffordable to the average student. }\end{array}$ & 3.077 & 0.27 \\
\hline $\begin{array}{l}\text { 12. Not making available (possibly through the college library) classroom materials that are costly and } \\
\text { unaffordable to the average student. }\end{array}$ & 3.240 & 0.40 \\
\hline 13. Disclosing students' grades with students' identity to other classmates. & 4.875 & 1.00 \\
\hline $\begin{array}{l}\text { 14. Disclosing students' grades to administrators who do not have official business with students' grades } \\
\text { and transcripts. }\end{array}$ & 4.400 & 0.88 \\
\hline $\begin{array}{l}\text { 15. Disclosing students' grades to faculty colleagues who do not have official business with students' } \\
\text { grades and transcripts. }\end{array}$ & 4.240 & 0.80 \\
\hline 16. Disclosing students' grades to their parents without the explicit permission of the student. & 4.560 & 0.88 \\
\hline 17. Not explaining to a student the reasons for receiving a certain grade. & 4.160 & 0.76 \\
\hline 18. Grading students inconsistently. & 4.600 & 0.96 \\
\hline $\begin{array}{l}\text { 19. Failing to assume responsibility for the safety of students in the conduct of field trips and study } \\
\text { abroad programs. }\end{array}$ & 4.300 & 0.85 \\
\hline 20. Choosing one's own textbook and/or other course materials for classroom use. & 3.360 & 0.48 \\
\hline 21. Choosing a textbook and/or other course materials authored by a friend. & 2.846 & 0.23 \\
\hline 22. Choosing a textbook and/or other course materials authored by a departmental colleague. & 3.038 & 0.31 \\
\hline $\begin{array}{l}\text { 23. Accepting meals, entertainment, and/or gift from a publisher whose goal is to influence textbook } \\
\text { adoption decisions. }\end{array}$ & 3.800 & 0.60 \\
\hline 24. Accepting relatives as students in one's class. & 3.000 & 0.36 \\
\hline 25. Teaching students one's own concepts and models, not those that are representative of the literature. & 3.038 & 0.35 \\
\hline $\begin{array}{l}\text { 26. Engaging in unbecoming behavior with students (e.g., drinking alcoholic beverages until feeling } \\
\text { intoxicated). }\end{array}$ & 4.640 & 0.88 \\
\hline $\begin{array}{l}\text { 27. Advising students to take courses to prepare them for exciting jobs (e.g., job in large advertising } \\
\text { agencies) knowing that chances are very remote in securing such jobs and not informing students about } \\
\text { the chances. }\end{array}$ & 3.885 & 0.65 \\
\hline 28. Request textbook desk copies outside area of teaching responsibility. & 3.680 & 0.52 \\
\hline 29. Tell "off-color" jokes in class to liven things up and gain students' approval. & 4.458 & 0.88 \\
\hline 30. Not show up repeatedly for office hours. & 4.385 & 0.96 \\
\hline $\begin{array}{l}\text { 31. Submitting a graduate student paper to a journal for the only purpose of getting a review and then } \\
\text { passing on the review to the student without acknowledging the source. }\end{array}$ & 4.640 & 0.96 \\
\hline $\begin{array}{l}\text { 32. Exaggerating or misrepresenting a student's skills and competence in writing a letter of } \\
\text { recommendation for the student. }\end{array}$ & 4.269 & 0.92 \\
\hline $\begin{array}{l}\text { 33. Developing a course syllabus and other teaching materials inconsistent with the college's standard } \\
\text { description of the course. }\end{array}$ & 3.577 & 0.50 \\
\hline 34. Not administering student evaluations because teacher anticipates negative student evaluations. & 4.500 & 0.96 \\
\hline
\end{tabular}




\begin{tabular}{|c|c|c|}
\hline Section II: Internal Audit Educators In Their Role As Researchers & Mean $^{a}$ & $\begin{array}{c}\text { Complete } \\
\text { Ratio }\end{array}$ \\
\hline 1. Having a romantic relationship with a student who volunteered as a research subject. & 3.875 & 0.92 \\
\hline 2. Expecting sexual favors in return for research credit. & 4.000 & 1.00 \\
\hline $\begin{array}{l}\text { 3. Giving research credit to subjects partly based on gender, religion, ethnicity, race, nationality, age, } \\
\text { sexual orientation, or physical/mental disability. }\end{array}$ & 4.000 & 1.00 \\
\hline 4. Not debriefing research subjects after their participation. & 3.652 & 0.70 \\
\hline $\begin{array}{l}\text { 5. Not disclosing to research subjects any aspects of the study likely to cause them physical and/or } \\
\text { psychological harm or discomfort. }\end{array}$ & 4.000 & 1.00 \\
\hline 6. Misleading research subjects about the amount of time needed to complete their task in the study. & 3.917 & 0.92 \\
\hline $\begin{array}{l}\text { 7. Not informing college/university officials about any aspect of research that may affect the } \\
\text { college/university in any adverse way. }\end{array}$ & 3.917 & 0.92 \\
\hline $\begin{array}{l}\text { 8. Not informing research sponsors about any aspect of the research that is discrepant from the original } \\
\text { expectations of the sponsor. }\end{array}$ & 3.875 & 0.92 \\
\hline $\begin{array}{l}\text { 9. Disclosing information about research subjects-information in which subjects were assured to be } \\
\text { treated confidentially. }\end{array}$ & 4.000 & 1.00 \\
\hline $\begin{array}{l}\text { 10. Disclosing information about the research sponsor-privileged information in which the research } \\
\text { sponsor was assured to be treated confidentially. }\end{array}$ & 4.000 & 1.00 \\
\hline 11. Not providing research subjects with deserved credit distributed fairly across all subjects. & 3.957 & 0.96 \\
\hline $\begin{array}{l}\text { 12. Not acknowledging the contribution of the research sponsor in research publications based on the } \\
\text { sponsored research. }\end{array}$ & 3.917 & 0.92 \\
\hline 13. Not considering the safety of research subjects in the conduct of the research. & 4.000 & 1.00 \\
\hline $\begin{array}{l}\text { 14. Working on a research project sponsored by an organization that expects the researcher to prove the } \\
\text { sponsor's legal position. }\end{array}$ & 3.667 & 0.71 \\
\hline $\begin{array}{l}\text { 15. Exaggerating and misrepresenting one's expertise and competence in a specific area of research to } \\
\text { secure a research contract. }\end{array}$ & 4.000 & 1.00 \\
\hline 16. Altering the research data to fit the researcher's theoretical notions. & 4.000 & 1.00 \\
\hline 17. Altering the research data to fit the expectation of the research sponsor. & 4.000 & 1.00 \\
\hline 18. Misrepresenting aspects of the research to ensure a positive peer review. & 4.000 & 1.00 \\
\hline $\begin{array}{l}\text { 19. Submitting a paper to a journal for the only purpose of getting a quality review knowing that the } \\
\text { paper is very likely to get rejected. }\end{array}$ & 3.250 & 0.38 \\
\hline $\begin{array}{l}\text { 20. Refusing to make the instrument/data available for scrutiny when requested for several years after } \\
\text { publication to encourage further testing and replication. }\end{array}$ & 3.750 & 0.79 \\
\hline 21. Engaging in idioplagiarism (i.e., copying major parts of one paper into another). & 3.833 & 0.83 \\
\hline 22. Submitting a paper to different journals at the same time. & 3.833 & 0.88 \\
\hline 23. Agreeing to present a paper at a conference, then send a graduate student to read the paper. & 3.565 & 0.65 \\
\hline $\begin{array}{l}\text { 24. Listing as a co-author a colleague who did not contribute substantively to the development of the } \\
\text { paper. }\end{array}$ & 3.783 & 0.78 \\
\hline $\begin{array}{l}\text { 25. Listing as a co-author a well-known author only to enhance the chances of the paper getting accepted } \\
\text { for publication. }\end{array}$ & 3.696 & 0.78 \\
\hline \multicolumn{3}{|l|}{ Section III: Internal Audit Educators In Their Role As Administrators } \\
\hline $\begin{array}{l}\text { 1. Informing faculty when first hired they will teach a certain course, then assigning a different course } \\
\text { without seeking approval from the faculty in question. }\end{array}$ & 3.455 & 0.59 \\
\hline $\begin{array}{l}\text { 2. Assigning merit raises to faculty based on standards and expectations not well articulated in a written } \\
\text { form. }\end{array}$ & 3.409 & 0.55 \\
\hline $\begin{array}{l}\text { 3. Informing faculty that research and scholarship is not a factor in tenure, promotion, and merit raises } \\
\text { but then using such criterion in performance evaluation. }\end{array}$ & 4.000 & 1.00 \\
\hline $\begin{array}{l}\text { 4. Informing faculty that student teaching evaluations are not a factor in tenure, promotion, and merit } \\
\text { raises but then using such a criterion in performance evaluation. }\end{array}$ & 3.909 & 0.91 \\
\hline $\begin{array}{l}\text { 5. Informing faculty that service (to the college, discipline, and business community) is not a factor in } \\
\text { tenure, promotion, and merit raises but then using such a criterion in performance evaluation. }\end{array}$ & 3.955 & 0.95 \\
\hline 6. Having a romantic relationship with a faculty member. & 3.364 & 0.50 \\
\hline $\begin{array}{l}\text { 7. Persuading faculty to join professional associations when there is a clear incentive for the } \\
\text { administrator. }\end{array}$ & 3.682 & 0.73 \\
\hline 8. Persuading faculty to adopt a certain textbook when there is a clear incentive for the administrator. & 3.682 & 0.73 \\
\hline 9. Expecting sexual favors from a faculty member in return for better evaluation or support. & 4.000 & 1.00 \\
\hline $\begin{array}{l}\text { 10. Assigning a faculty member a heavy teaching load in an attempt to force him/her to resign from the } \\
\text { institution. }\end{array}$ & 3.364 & 0.59 \\
\hline
\end{tabular}




\begin{tabular}{|c|c|c|}
\hline $\begin{array}{l}\text { 11. Evaluating faculty performance partly based on gender, religion, ethnicity, race, nationality, age, } \\
\text { sexual orientation, or physical/mental disability. }\end{array}$ & 3.955 & 0.95 \\
\hline $\begin{array}{l}\text { 12. Recruiting new faculty partly based on gender, religion, ethnicity, race, nationality, age sexual } \\
\text { orientation, or physical/mental disability. }\end{array}$ & 3.455 & 0.68 \\
\hline $\begin{array}{l}\text { 13. Allocating teaching/service/research assignments partly based on gender, religion, ethnicity, race, } \\
\text { nationality, age, sexual orientation, or physical/mental disability. }\end{array}$ & 3.818 & 0.91 \\
\hline 14. Not providing faculty with adequate and timely information about performance evaluation. & 3.864 & 0.86 \\
\hline 15. Not providing faculty with adequate and timely information about changes in resources and policies. & 3.773 & 0.77 \\
\hline 16. Not providing faculty with adequate classroom space and multimedia equipment. & 3.409 & 0.45 \\
\hline 17. Not providing faculty with adequate research facilities and resources. & 3.409 & 0.50 \\
\hline 18. Not providing faculty with adequate office space. & 3.318 & 0.50 \\
\hline $\begin{array}{l}\text { 19. Not providing faculty with adequate travel resources to attend at least one professional conference } \\
\text { per year of the faculty's choice. }\end{array}$ & 3.455 & 0.59 \\
\hline $\begin{array}{l}\text { 20. Disclosing information about a faculty member's performance to others who are not authorized to } \\
\text { have this information. }\end{array}$ & 3.864 & 0.86 \\
\hline 21. Disclosing negative, non-performance information about a faculty member to others. & 3.864 & 0.86 \\
\hline 22. Failing to discuss a faculty member's performance evaluation with him/her. & 3.909 & 0.91 \\
\hline 23. Refusing to implement procedures that would allow faculty to express grievance. & 3.909 & 0.91 \\
\hline 24. Evaluating faculty inconsistently using different standards. & 3.955 & 0.95 \\
\hline $\begin{array}{l}\text { 25. Failing to acknowledge significant contributions of a faculty member in departmental/college } \\
\text { publications. }\end{array}$ & 3.909 & 0.91 \\
\hline 26. Failing to compensate faculty for teaching overloads. & 3.636 & 0.73 \\
\hline 27. Assigning faculty to work in unsafe facilities. & 4.000 & 1.00 \\
\hline 28. Hiring faculty motivated by personal or professional gain. & 3.864 & 0.91 \\
\hline 29. Allocating resources to faculty motivated by personal or professional gain. & 3.864 & 0.91 \\
\hline 30. Terminating faculty motivated by personal or professional gain. & 3.909 & 0.91 \\
\hline 31. Making committee assignments to faculty motivated by personal or professional gain. & 3.864 & 0.86 \\
\hline 32. Failing to adhere to policies and contracts in managing faculty. & 4.000 & 1.00 \\
\hline \multicolumn{3}{|l|}{ Section IV: Internal Audit Educators In Relation To Graduate Students } \\
\hline $\begin{array}{l}\text { 1. Informing a graduate student when first recruited into the program s/he will work on a certain project } \\
\text { with a certain faculty and then assigning him/her to another project with another faculty without seeking } \\
\text { approval from the student. }\end{array}$ & 3.545 & 0.68 \\
\hline 2. Having a romantic relationship with a graduate student. & 3.773 & 0.86 \\
\hline 3. Expecting sexual favors from a graduate student in return for better evaluation or support. & 3.909 & 0.95 \\
\hline $\begin{array}{l}\text { 4. Assigning a graduate student projects requiring a great deal of work in an attempt to force him/her to } \\
\text { resign from the program. }\end{array}$ & 3.545 & 0.68 \\
\hline 5. Not providing graduate students with adequate and timely information about performance evaluation. & 3.818 & 0.86 \\
\hline $\begin{array}{l}\text { 6. Not providing graduate students with adequate and timely information about changes in the degree } \\
\text { program, resources, and policies. }\end{array}$ & 3.818 & 0.86 \\
\hline $\begin{array}{l}\text { 7. Not providing graduate students with adequate office space and supplies to allow them to carry out } \\
\text { their assigned tasks. }\end{array}$ & 3.409 & 0.55 \\
\hline $\begin{array}{l}\text { 8. Making admission decisions to graduate programs partly based on gender, religion, ethnicity, race, } \\
\text { nationality, age, sexual orientation, or physical/mental disability. }\end{array}$ & 3.500 & 0.68 \\
\hline $\begin{array}{l}\text { 9. Disclosing information about a graduate student's performance to others who are not authorized to } \\
\text { have this information. }\end{array}$ & 3.909 & 0.95 \\
\hline 10. Disclosing negative, non-performance information about a graduate student to others. & 3.864 & 0.91 \\
\hline 11. Assigning graduate students to work in an unsafe environment. & 3.909 & 0.95 \\
\hline 12. Recruiting graduate students motivated by personal gain. & 3.818 & 0.86 \\
\hline 13. Allocating resources to graduate students guided by personal gain. & 3.773 & 0.82 \\
\hline 14. Terminating graduate students motivated by personal gain. & 3.727 & 0.77 \\
\hline 15. Assigning advisors and projects to graduate students guided by personal gain. & 3.727 & 0.77 \\
\hline 16. Failing to adhere to policies and contracts in managing graduate students. & 3.810 & 0.86 \\
\hline
\end{tabular}

${ }^{\mathrm{a}}$ A 5- point rating scale was used: $1=$ IS very acceptable, $2=$ MAY be acceptable, $3=$ MAY BE Unacceptable, $4=$ IS Unacceptable, 5= IS very unacceptable.

${ }^{\mathrm{b}}$ The complete ratio represents the percentage of respondents that rated the behavior as either 4 (unacceptable) or 5 (very unacceptable) 


\section{COMPARATIVE ANALYSIS}

Identical surveys were used for the study drawing on the one developed by Sirgy et al. (2005). The authors in that study used the 2001-2002 Hasselback directory to select 1,000 accounting faculty out of a possible 8,251 to receive a mail questionnaire. There were 151 usable responses $(15.1 \%)$. The internal auditor survey response rate in this study was $21.5 \%$. The higher response rate may be due to the fact that a specific community was targeted (i.e., internal audit educators), so they may have been more personally interested in the survey than the accounting faculty in the Sirgy study who represented a variety of communities (e.g., auditing instructors, internal auditors, and tax faculty). The comparative results of both surveys are presented in Table 2.

Table 2: Hypernorms for Both Accounting Educators and Internal Audit Educators

\begin{tabular}{|c|c|c|}
\hline \multirow[b]{2}{*}{ Section I: Internal Audit Educators In Their Role As Teachers } & \multicolumn{2}{|c|}{$\begin{array}{l}\text { Met Hypernorm } \\
\text { Criteria }\end{array}$} \\
\hline & Accounting & $\begin{array}{c}\text { Internal } \\
\text { Audit }\end{array}$ \\
\hline $\begin{array}{l}\text { 1. Informing students they will be tested with one type of exam and then giving them another } \\
\text { type of exam. }\end{array}$ & Hypernorm & Hypernorm \\
\hline $\begin{array}{l}\text { 2. Deviating significantly from the course syllabus given to students at the beginning of the } \\
\text { semester. }\end{array}$ & No & No \\
\hline $\begin{array}{l}\text { 3. Informing students that attendance is not a factor in grades and then using attendance as a } \\
\text { grade criterion when a student misses classes. }\end{array}$ & Hypernorm & Hypernorm \\
\hline 4. Having a romantic relationship with a student in one's class. & Hypernorm & Hypernorm \\
\hline $\begin{array}{l}\text { 5. Persuading students to join professional associations when there is a personal or professional } \\
\text { incentive for the teacher. }\end{array}$ & No & No \\
\hline $\begin{array}{l}\text { 6. Persuading students to subscribe to trade journals and magazines when there is a personal or } \\
\text { professional incentive for the teacher. }\end{array}$ & No & Hypernorm \\
\hline 7. Expecting sexual favors in return for better grades or support. & Hypernorm & Hypernorm \\
\hline $\begin{array}{l}\text { 8. Treating students in class more favorably based on their gender, religion, ethnicity, race, } \\
\text { nationality, age, sexual orientation, or physical/mental disability. }\end{array}$ & Hypernorm & Hypernorm \\
\hline $\begin{array}{l}\text { 9. Treating students in class less favorably based on their gender, religion, ethnicity, race, } \\
\text { nationality, age, sexual orientation, or physical/mental disability. }\end{array}$ & Hypernorm & Hypernorm \\
\hline $\begin{array}{l}\text { 10. Not providing students with a course syllabus at the beginning of the semester that spells out } \\
\text { the nature of the course, course requirements, grading procedures, and other issues of course } \\
\text { implementation. }\end{array}$ & Hypernorm & Hypernorm \\
\hline $\begin{array}{l}\text { 11. Requiring students to purchase textbooks and other classroom materials that are costly and } \\
\text { unaffordable to the average student. }\end{array}$ & No & No \\
\hline $\begin{array}{l}\text { 12. Not making available (possibly through the college library) classroom materials that are } \\
\text { costly and unaffordable to the average student. }\end{array}$ & No & No \\
\hline 13. Disclosing students' grades with students' identity to other classmates. & Hypernorm & Hypernorm \\
\hline $\begin{array}{l}\text { 14. Disclosing students' grades to administrators who do not have official business with } \\
\text { students' grades and transcripts. }\end{array}$ & No & Hypernorm \\
\hline $\begin{array}{l}\text { 15. Disclosing students' grades to faculty colleagues who do not have official business with } \\
\text { students' grades and transcripts. }\end{array}$ & No & Hypernorm \\
\hline 16. Disclosing students' grades to their parents without the explicit permission of the student. & No & Hypernorm \\
\hline 17. Not explaining to a student the reasons for receiving a certain grade. & Hypernorm & Hypernorm \\
\hline 18. Grading students inconsistently. & Hypernorm & Hypernorm \\
\hline $\begin{array}{l}\text { 19. Failing to assume responsibility for the safety of students in the conduct of field trips and } \\
\text { study abroad programs. }\end{array}$ & No & Hypernorm \\
\hline 20. Choosing one's own textbook and/or other course materials for classroom use. & No & No \\
\hline 21. Choosing a textbook and/or other course materials authored by a friend. & No & No \\
\hline 22. Choosing a textbook and/or other course materials authored by a departmental colleague. & No & No \\
\hline $\begin{array}{l}\text { 23. Accepting meals, entertainment, and/or gift from a publisher whose goal is to influence } \\
\text { textbook adoption decisions. }\end{array}$ & No & No \\
\hline 24. Accepting relatives as students in one's class. & No & No \\
\hline $\begin{array}{l}\text { 25. Teaching students one's own concepts and models, not those that are representative of the } \\
\text { literature. }\end{array}$ & No & No \\
\hline
\end{tabular}




\begin{tabular}{|c|c|c|}
\hline $\begin{array}{l}\text { 26. Engaging in unbecoming behavior with students (e.g., drinking alcoholic beverages until } \\
\text { feeling intoxicated). }\end{array}$ & No & Hypernorm \\
\hline $\begin{array}{l}\text { 27. Advising students to take courses to prepare them for exciting jobs (e.g., job in large } \\
\text { advertising agencies) knowing that chances are very remote in securing such jobs and not } \\
\text { informing students about the chances. }\end{array}$ & No & No \\
\hline 28. Request textbook desk copies outside area of teaching responsibility. & No & No \\
\hline 29. Tell "off-color" jokes in class to liven things up and gain students' approval. & No & Hypernorm \\
\hline 30. Not showing up repeatedly for office hours. & Hypernorm & Hypernorm \\
\hline $\begin{array}{l}\text { 31. Submitting a graduate student paper to a journal for the only purpose of getting a review and } \\
\text { then passing on the review to the student without acknowledging the source. }\end{array}$ & Hypernorm & Hypernorm \\
\hline $\begin{array}{l}\text { 32. Exaggerating or misrepresenting a student's skills and competence in writing a letter of } \\
\text { recommendation for the student. }\end{array}$ & No & Hypernorm \\
\hline $\begin{array}{l}\text { 33. Developing a course syllabus and other teaching materials inconsistent with the college's } \\
\text { standard description of the course. }\end{array}$ & No & No \\
\hline $\begin{array}{l}\text { 34. Not administering student evaluations because teacher anticipates negative student } \\
\text { evaluations. }\end{array}$ & No & Hypernorm \\
\hline \multicolumn{3}{|l|}{ Section II: Internal Audit Educators In Their Role As Researchers } \\
\hline 1. Having a romantic relationship with a student who volunteered as a research subject. & Hypernorm & No \\
\hline 2. Expecting sexual favors in return for research credit. & Hypernorm & Hypernorm \\
\hline $\begin{array}{l}\text { 3. Giving research credit to subjects partly based on gender, religion, ethnicity, race, nationality, } \\
\text { age, sexual orientation, or physical/mental disability. }\end{array}$ & Hypernorm & Hypernorm \\
\hline 4. Not debriefing research subjects after their participation. & No & No \\
\hline $\begin{array}{l}\text { 5. Not disclosing to research subjects any aspects of the study likely to cause them physical } \\
\text { and/or psychological harm or discomfort. }\end{array}$ & Hypernorm & Hypernorm \\
\hline $\begin{array}{l}\text { 6. Misleading research subjects about the amount of time needed to complete their task in the } \\
\text { study. }\end{array}$ & Hypernorm & No \\
\hline $\begin{array}{l}\text { 7. Not informing college/university officials about any aspect of research that may affect the } \\
\text { college/university in any adverse way. }\end{array}$ & Hypernorm & No \\
\hline $\begin{array}{l}\text { 8. Not informing research sponsors about any aspect of the research that is discrepant from the } \\
\text { original expectations of the sponsor. }\end{array}$ & Hypernorm & No \\
\hline $\begin{array}{l}\text { 9. Disclosing information about research subjects-information in which subjects were assured } \\
\text { to be treated confidentially. }\end{array}$ & Hypernorm & Hypernorm \\
\hline $\begin{array}{l}\text { 10. Disclosing information about the research sponsor-privileged information in which the } \\
\text { research sponsor was assured to be treated confidentially. }\end{array}$ & Hypernorm & Hypernorm \\
\hline 11. Not providing research subjects with deserved credit distributed fairly across all subjects. & Hypernorm & No \\
\hline $\begin{array}{l}\text { 12. Not acknowledging the contribution of the research sponsor in research publications based } \\
\text { on the sponsored research. }\end{array}$ & Hypernorm & No \\
\hline 13. Not considering the safety of research subjects in the conduct of the research. & Hypernorm & Hypernorm \\
\hline $\begin{array}{l}\text { 14. Working on a research project sponsored by an organization that expects the researcher to } \\
\text { prove the sponsor's legal position. }\end{array}$ & No & No \\
\hline $\begin{array}{l}\text { 15. Exaggerating and misrepresenting one's expertise and competence in a specific area of } \\
\text { research to secure a research contract. }\end{array}$ & Hypernorm & Hypernorm \\
\hline 16. Altering the research data to fit the researcher's theoretical notions. & Hypernorm & Hypernorm \\
\hline 17. Altering the research data to fit the expectation of the research sponsor. & Hypernorm & Hypernorm \\
\hline 18. Misrepresenting aspects of the research to ensure a positive peer review. & Hypernorm & Hypernorm \\
\hline $\begin{array}{l}\text { 19. Submitting a paper to a journal for the only purpose of getting a quality review knowing that } \\
\text { the paper is very likely to get rejected. }\end{array}$ & No & No \\
\hline $\begin{array}{l}\text { 20. Refusing to make the instrument/data available for scrutiny when requested for several years } \\
\text { after publication to encourage further testing and replication. }\end{array}$ & No & No \\
\hline 21. Engaging in idioplagiarism (i.e., copying major parts of one paper into another). & No & No \\
\hline 22. Submitting a paper to different journals at the same time. & No & No \\
\hline 23. Agreeing to present a paper at a conference, then send a graduate student to read the paper. & No & No \\
\hline $\begin{array}{l}\text { 24. Listing as a co-author a colleague who did not contribute substantively to the development of } \\
\text { the paper. }\end{array}$ & No & No \\
\hline $\begin{array}{l}\text { 25. Listing as a co-author a well-known author only to enhance the chances of the paper getting } \\
\text { accepted for publication. }\end{array}$ & No & No \\
\hline
\end{tabular}




\begin{tabular}{|c|c|c|}
\hline Section III: Internal Audit Educators In Their Role As Administrators & & \\
\hline $\begin{array}{l}\text { 1. Informing faculty when first hired they will teach a certain course, then assigning a different } \\
\text { course without seeking approval from the faculty in question. }\end{array}$ & No & No \\
\hline $\begin{array}{l}\text { 2. Assigning merit raises to faculty based on standards and expectations not well articulated in a } \\
\text { written form. }\end{array}$ & No & No \\
\hline $\begin{array}{l}\text { 3. Informing faculty that research and scholarship is not a factor in tenure, promotion, and merit } \\
\text { raises but then using such criterion in performance evaluation. }\end{array}$ & Hypernorm & Hypernorm \\
\hline $\begin{array}{l}\text { 4. Informing faculty that student teaching evaluations are not a factor in tenure, promotion, and } \\
\text { merit raises but then using such a criterion in performance evaluation. }\end{array}$ & Hypernorm & No \\
\hline $\begin{array}{l}\text { 5. Informing faculty that service (to the college, discipline, and business community) is not a } \\
\text { factor in tenure, promotion, and merit raises but then using such a criterion in performance } \\
\text { evaluation. }\end{array}$ & Hypernorm & No \\
\hline 6. Having a romantic relationship with a faculty member. & No & No \\
\hline $\begin{array}{l}\text { 7. Persuading faculty to join professional associations when there is a clear incentive for the } \\
\text { administrator. }\end{array}$ & No & No \\
\hline $\begin{array}{l}\text { 8. Persuading faculty to adopt a certain textbook when there is a clear incentive for the } \\
\text { administrator. }\end{array}$ & No & No \\
\hline 9. Expecting sexual favors from a faculty member in return for better evaluation or support. & Hypernorm & Hypernorm \\
\hline $\begin{array}{l}\text { 10. Assigning a faculty member a heavy teaching load in an attempt to force him/her to resign } \\
\text { from the institution. }\end{array}$ & No & No \\
\hline $\begin{array}{l}\text { 11. Evaluating faculty performance partly based on gender, religion, ethnicity, race, nationality, } \\
\text { age, sexual orientation, or physical/mental disability. }\end{array}$ & Hypernorm & No \\
\hline $\begin{array}{l}\text { 12. Recruiting new faculty partly based on gender, religion, ethnicity, race, nationality, age } \\
\text { sexual orientation, or physical/mental disability. }\end{array}$ & No & No \\
\hline $\begin{array}{l}\text { 13. Allocating teaching/service/research assignments partly based on gender, religion, ethnicity, } \\
\text { race, nationality, age, sexual orientation, or physical/mental disability. }\end{array}$ & No & No \\
\hline 14. Not providing faculty with adequate and timely information about performance evaluation. & Hypernorm & No \\
\hline $\begin{array}{l}\text { 15. Not providing faculty with adequate and timely information about changes in resources and } \\
\text { policies. }\end{array}$ & Hypernorm & No \\
\hline 16. Not providing faculty with adequate classroom space and multimedia equipment. & No & No \\
\hline 17. Not providing faculty with adequate research facilities and resources. & No & No \\
\hline 18. Not providing faculty with adequate office space. & No & No \\
\hline $\begin{array}{l}\text { 19. Not providing faculty with adequate travel resources to attend at least one professional } \\
\text { conference per year of the faculty's choice. }\end{array}$ & No & No \\
\hline $\begin{array}{l}\text { 20. Disclosing information about a faculty member's performance to others who are not } \\
\text { authorized to have this information. }\end{array}$ & Hypernorm & No \\
\hline 21. Disclosing negative, non-performance information about a faculty member to others. & Hypernorm & No \\
\hline 22. Failing to discuss a faculty member's performance evaluation with him/her. & Hypernorm & No \\
\hline 23. Refusing to implement procedures that would allow faculty to express grievance. & Hypernorm & No \\
\hline 24. Evaluating faculty inconsistently using different standards. & Hypernorm & No \\
\hline $\begin{array}{l}\text { 25. Failing to acknowledge significant contributions of a faculty member in departmental/college } \\
\text { publications. }\end{array}$ & Hypernorm & No \\
\hline 26. Failing to compensate faculty for teaching overloads. & Hypernorm & No \\
\hline 27. Assigning faculty to work in unsafe facilities. & Hypernorm & Hypernorm \\
\hline 28. Hiring faculty motivated by personal or professional gain. & No & No \\
\hline 29. Allocating resources to faculty motivated by personal or professional gain. & No & No \\
\hline 30. Terminating faculty motivated by personal or professional gain. & Hypernorm & No \\
\hline 31. Making committee assignments to faculty motivated by personal or professional gain. & No & No \\
\hline 32. Failing to adhere to policies and contracts in managing faculty. & Hypernorm & Hypernorm \\
\hline \multicolumn{3}{|l|}{ Section IV: Internal Audit Educators In Relation To Graduate Students } \\
\hline $\begin{array}{l}\text { 1. Informing a graduate student when first recruited into the program s/he will work on a certain } \\
\text { project with a certain faculty and then assigning him/her to another project with another faculty } \\
\text { without seeking approval from the student. }\end{array}$ & No & No \\
\hline 2. Having a romantic relationship with a graduate student. & Hypernorm & No \\
\hline 3. Expecting sexual favors from a graduate student in return for better evaluation or support. & Hypernorm & No \\
\hline $\begin{array}{l}\text { 4. Assigning a graduate student projects requiring a great deal of work in an attempt to force } \\
\text { him/her to resign from the program. }\end{array}$ & Hypernorm & No \\
\hline
\end{tabular}




\begin{tabular}{|l|c|c|}
\hline $\begin{array}{l}\text { 5. Not providing graduate students with adequate and timely information about performance } \\
\text { evaluation. }\end{array}$ & Hypernorm & No \\
\hline $\begin{array}{l}\text { 6. Not providing graduate students with adequate and timely information about changes in the } \\
\text { degree program, resources, and policies. }\end{array}$ & Hypernorm & No \\
\hline $\begin{array}{l}\text { 7. Not providing graduate students with adequate office space and supplies to allow them to } \\
\text { carry out their assigned tasks. }\end{array}$ & No & No \\
\hline $\begin{array}{l}\text { 8. Making admission decisions to graduate programs partly based on gender, religion, ethnicity, } \\
\text { race, nationality, age, sexual orientation, or physical/mental disability. }\end{array}$ & No & No \\
\hline $\begin{array}{l}\text { 9. Disclosing information about a graduate student's performance to others who are not } \\
\text { authorized to have this information. }\end{array}$ & Hypernorm & No \\
\hline 10. Disclosing negative, non-performance information about a graduate student to others. & Hypernorm & No \\
\hline 11. Assigning graduate students to work in an unsafe environment. & Hypernorm & No \\
\hline 12. Recruiting graduate students motivated by personal gain. & No & No \\
\hline 13. Allocating resources to graduate students guided by personal gain. & No & No \\
\hline 14. Terminating graduate students motivated by personal gain. & Hypernorm & No \\
\hline 15. Assigning advisors and projects to graduate students guided by personal gain. & Hypernorm & No \\
\hline 16. Failing to adhere to policies and contracts in managing graduate students. & Hypernorm & No \\
\hline
\end{tabular}

\section{Hypernorms of the Accounting and Internal Audit Educators}

The identified hypernorms common to accounting and internal auditing educators in Table 2 reflect a variety of unacceptable behaviors. A summary of these behaviors appears in Table 3.

Many of these hypernorms have to do with sexual misconduct, safety, fraudulent or misleading information, treating students unfairly, and breaches of confidentiality. The following principles of behavior (Table 4) were drawn from the results with respect to educator roles as teachers and researchers might serve as the basis of a code of ethics for academic accountants. We omit the educators' role as administrators because there was no way of knowing whether surveyed faculty held such positions. There were no hypernorms for internal audit educators in relation to graduate students. 


\section{Possible Hypernorms for Internal Auditing and Accounting Educators Table 3}

\section{Section I - The Respective Educators in Their Role as Teachers}

1. Informing students they will be tested with one type of exam and then giving them another type of exam.

3. Informing students that attendance is not a factor in grades and then using attendance as a grade criterion when a student misses classes.

4. Having a romantic relationship with a student in one's class.

7. Expecting sexual favors in return for better grades or support.

8. Treating students in class more favorably based on their gender, religion, ethnicity, race, nationality, age, sexual orientation, or physical/mental disability.

9. Treating students in class less favorably based on their gender, religion, ethnicity, race, nationality, age, sexual orientation, or physical/mental disability.

10. Not providing students with a course syllabus at the beginning of the semester that spells out the nature of the course, course requirements, grading procedures, and other issues of course implementation.

13. Disclosing students' grades with students' identity to other classmates.

17. Not explaining to a student the reasons for receiving a certain grade.

18. Grading students inconsistently.

30. Not show up repeatedly for office hours.

31. Submitting a graduate student paper to a journal for the only purpose of getting a review and then passing on the review to the student without acknowledging the source.

\section{Section II - The Respective Educators in their Role as Researchers}

2. Expecting sexual favors in return for research credit.

3. Giving research credit to subjects partly based on gender, religion, ethnicity, race, nationality, age, sexual orientation, or physical/mental disability.

5. Not disclosing to research subjects any aspects of the study likely to cause them physical and/or psychological harm or discomfort.

9. Disclosing information about research subjects - information in which subjects were assured to be treated confidentially.

10. Disclosing information about the research sponsor-privileged information in which the research sponsor was assured to be treated confidentially.

13. Not considering the safety of research subjects in the conduct of the research.

15. Exaggerating and misrepresenting one's expertise and competence in a specific area of research to secure a research contract.

16. Altering the research data to fit the researcher's theoretical notions.

17. Altering the research data to fit the expectation of the research sponsor.

18. Misrepresenting aspects of the research to ensure a positive peer review.

\section{Section III - The Respective Educators in their Role as Administrators}

3. Informing faculty that research and scholarship is not a factor in tenure, promotion, and merit raises but then using such criterion in performance evaluation.

9. Expecting sexual favors from a faculty member in return for better evaluation or support.

27. Assigning faculty to work in unsafe facilities.

32. Failing to adhere to policies and contracts in managing faculty.

\section{Section IV - Respective Educators in Relation to Graduate Students}

There were no behaviors in Section IV in the respective educators studies identified as a hypernorm exclusively by the respective educators. 
Table 4: Principals of Behavior as Related to Educator Role

\begin{tabular}{|lll|}
\hline & Educator Role & Hypernorms \\
1. $\quad$ Bole as a Teacher & $1,3,17,31$ \\
2. $\quad$ Avoid personal relationships that might bias one's evaluation of students & 4,7 \\
3. $\quad$ Treat students fairly in evaluating their work and classroom performance & $8,9,18$ \\
4. $\quad$ Be reliable and competent in meeting teaching responsibilities & 10,30 \\
5. $\quad$ Maintain the confidentiality of student coursework and records & 13 \\
& & Hypernorms \\
& Role as Researchers & 2,3 \\
1. & Avoid personal relationships that might bias one's evaluation of students & 5,13 \\
2. $\quad$ Inform students of potential safety issues prior to engaging in research & 9,10 \\
3. $\quad$ Maintain the confidentiality of research subjects and sponsors & $15,16,17,18$ \\
4. Conduct research competently and present research data truthfully &
\end{tabular}

\section{CONCLUSION: DEVELOPING A CODE OF ETHICS}

In recent years, professional associations have identified ethics standards for members of their organization. The International Association for Accounting Education and Research (IAAER 2009), the worldwide association of accounting academics dedicated to promote excellence in accounting education and research on a worldwide basis, developed a Global Code of Ethics that addresses accounting educators' responsibilities in three broad areas: accounting education; academic research; and service to the accounting profession. The Code is intended to raise the awareness of accounting academics in all countries to their responsibilities for setting examples for ethical behavior for their students and with their colleagues. The responsibilities of accounting educators include among others: professional ethics should pervade the teaching of accounting; teaching and a concern for student learning; accept responsibility for competent, inspirational, scholarly instruction; and respect for integrity and teaching scholarship.

Many observers believe that the simple existence of an ethics code within the business academe is not sufficient to guarantee ethical behavior (e.g., Dean 1992; Kohut \& Corriher 1994; Lawrence 1976; McDonald \& Nijhof 1999; Nixon et al. 1992; Pajo \& McGhee 2003; Soutar et al. 1994; Stead et al. 1990; Trevino et al. 1999). Wiley (1995) suggests that if codes are to be effective then they must be specific, public, clear and practical, revisable, and enforceable. Dean (1992) points out that a code of ethics for educators can serve as an effective educational guide for educators.

The AACSB International (AACSBI 2004) recognizes the importance of developing a code of ethics for business educators in its 2004 report to its Board of Directors. The Ethics Education Task Force prepared a paper for the AACSB titled "Ethics Education in Business Schools." The Task Force states its belief that ethical behavior is of great importance in the delivery of quality business education. In the report member schools are encouraged to develop a code of ethics, conduct, or an honor code as well as a disciplinary system. Criterion $\mathrm{E}$ of the current accreditation standards states that business schools must establish expectations for ethical behavior for administrators, faculty, and students. The Task Force goes on to say: "Schools will do this with codes of conduct, values statements, honor codes...” (AACSBI 2004, 20).

The above standards of behavior drawn from the comparative results of the two surveys help to define the ethical obligations of accounting educators in meeting their academic responsibilities. The identified hypernorms provide examples of such behaviors. Even though the purpose of the paper was not to develop a code of ethics for accounting educators, it is a natural extension of the results of the survey comparisons to identify ethics standards. We hope the results inform administrators and boards of trustees about the ethical expectations for faculty in their roles as educators and researchers. Moreover, given the recent financial crisis that followed on the heels of accounting frauds at companies such as Enron and WorldCom, we believe accounting educators including those who teach internal auditing should be held to the highest ethical standards and serve as a role model for their students who will enter the accounting profession upon graduation. 


\section{LIMITATIONS AND FUTURE RESEARCH}

Our study relies on social contract theory to develop hypernorms. According to business ethics scholars who have applied social contract theory (Donaldson 1992; Donaldson \& Dunfee 1994; Donaldson \& Dunfee 1999; Dunfee 1991), a code of ethics can be developed by identifying evidence of hypernorms among key stakeholders. However, social contract theory has its critics. For example, Soule (2002) argues that while social contract theory is arguably the most promising candidate to effectively develop codes of ethics in business, it does have serious shortcomings. Soule maintains that social contract theory lacks sufficient moral content. That is, developing a code of ethics based on what educators believe as acceptable or unacceptable ethical behavior may result in a "morally weak" code of ethics. What if most educators do not recognize certain behaviors as unethical while the same behaviors are clearly recognized as unethical by other theories of moral and professional conduct?

This study focuses on two key stakeholder groups - all accounting educators and internal auditing educators. One limitation is that our survey respondents were overwhelmingly from North America. Given the IAAER's Global Code of Ethics for Accounting Educators, a truly international survey might provide interesting results to assess whether the perceived ethicality of behaviors differ among educators around the world.

Another limitation is that a critic may argue that those who complete ethics surveys are more likely to be ethically sensitive than those who do not complete these surveys. If so, the results of our study may be biased. The results are likely to be skewed in the direction of more agreement of behaviors identified as "unacceptable" than "acceptable." For example, our descriptive findings show none of 107 behaviors included in the survey qualify as "acceptable behaviors" a mean close to or smaller than two (i.e., the behavior is acceptable). The closest to acceptability is "Choosing a textbook and/or other course materials authored by a friend" (mean $=2.846$ ). The potentially skewed nature of responses attests to the need for future research to test differences between respondents and non-respondents. We were only able to test differences between early respondents and late respondents. Also, future research might use sampling techniques that can effectively reduce the non-response rate, therefore better deal with the problem of selection bias.

To counteract potential bias, our study applies stringent standards to identify hypernorms. We did this by drawing upon the literature on face validity (Hardesty and Bearden 2004) and we use two measurement methods to identify items considered as hypernorms: Sumscore and Complete methods. Recall that the two standards were: (1) a mean of 4 or above (showing an average view of "unacceptable" or "very unacceptable") and (2) a combined frequency percentage of $75 \%$ for judges rating a behavior as either 4 ("unacceptable") or 5 ("very unacceptable"). While we used $75 \%$ as the complete representation cutoff value, Saxe and Weitz (1982), Manning et al. (1995), and Sharma et al. (1990) recommend 50\%, 60\%, and 70\% of their judges, respectively, to rate an item as completely representative in order to be retained.

Despite the study limitations, we feel that our findings make an important contribution to the literature on academic ethics. Students can be influenced in their behavior as professionals based on classroom experiences and interactions with faculty. For example, one author encountered a student who argued for a higher grade on an exam even after the instructor explained his basis for grading. After ten minutes of debate, the instructor cut off discussion and advised the student to be careful not to be too argumentative in an on the job situation because it may negatively affect his performance evaluation. Unfortunately, the student did not seem to grasp the point and continued to argue perhaps hoping to "wear the instructor down."

\section{AUTHOR INFORMATION}

Philip H. Siegel is currently associated with McCurry and Co. CPAs in Boca Raton, Fl. He received his Ph. D. in a accounting from the University of Memphis and is a CPA active Florida. He has had research published in the Journal of Accounting, Auditing and Finance; Research in Accounting Regulation; Journal of Business Ethics and other peer reviewed journals. E-mail: phsiegel2@yahoo.com 
Steven Mintz is a professor of accounting in the Orfalea College of Business at the California Polytechnic State University in San Luis Obispo. Dr. Mintz enjoys an international reputation as a leader in academic ethics. His textbook titled Ethical Obligations and Decision Making in Accounting: Text and Cases ( $2^{\text {nd }}$ edition) was published by McGraw-Hill Irwin in 2010 and is used in about 40 universities to teach ethics to accounting students. Steve has published more than 20 research papers on international accounting and ethics and made dozens of presentations to professional and academic groups. E-mail: smintz@calpoly.edu

Mohsen Naser-Tavakolian is currently a CMA and a professor of accounting and accounting information systems at San Francisco State University. He received his PH. D. in Accountancy from University of Missouri-Columbia. He has had research in the areas of Internal Audit and Academic Internships and he has published in Internal Auditor Journal and International Journal of Accounting Information Science and Leadership and has made presentations in professional conferences. E-mail: mntavako@sfsu.edu. Corresponding author.

John O'Shaughnessy is a professor of accounting at San Francisco State University. His research interests are in financial accounting and internal auditing. E-mail: joshaun@sfsu.edu

\section{REFERENCES}

1. Association to Advance Collegiate Schools of Business International (AASCBI), Ethics Education Taskforce, Ethics Education in Business Schools, St. Louis, MO: AACSB, 2004.

2. $\quad$ Birkett, W. P., Codifying Power and Control: Ethical Codes in Action, New York, NY:, 1999.

3. Coe, T. \& B. Coe, "Marketing research: The search for professionalism," In: Marketing: 1776-1976 and Beyond, edited by Kenneth L. Bernhardt, American Marketing Association, Chicago, IL, 1979.

4. Dean, P. J., "Making Codes of Ethics 'Real,' '’ Journal of Business Ethics, 11 (No. 4, 1992), 285-290.

5. Donaldson, T., Corporations and Morality, Prentice-Hall, Englewood Cliffs, NJ, 1992.

6. Donaldson, T. and T. W. Dunfee, "Toward a Unified Conception of Business Ethics: Integrative Social Contracts Theory, Academy of Management Review, (No. 19, 1994), 252-284.

7. Donaldson, T. and T. W. Dunfee, Ties that Bind: A Social Contracts Approach to Business Ethics, Harvard University Press, Cambridge, MA, 1994.

8. Dunfee, T. W., "Business Ethics and Extant Social Contracts," Business Ethics Quarterly, (No. 1, 1991), 23-51.

9. Ferrell, O. C., "An Assessment of the Proposed Academy of Marketing Science Code of Ethics for Marketing Educators," Journal of Business Ethics, 19 (April 1999), 225-228.

10. Ferrell, O. C. and S. J. Skinner, "Ethical Behavior and Bureaucratic Structure in Marketing Research Organizations," Journal of Marketing Research, 25 (February 1988), 103-109.

11. Flanagan, J. C., "The Critical Incident Technique," Psychological Bulletin, (No. 51, 1954), 327-343.

12. Hardesty, D. M. \& W. O. Bearden, "The Use of Expert Judges in Scale Development: Implications for Improving Face Validity of Measures of Unobservable Constructs," Journal of Business Research, (No. 57, 2004), 98-107.

13. International Association for Accounting Education and Research (IAAER), A Global Code of Ethics for Accounting Educators, 2009, Available at: http://www.iaaer.org.

14. Kohut, G.F. \& S. E. Corriher, The Relationship of Age, Gender, Experience and Awareness of Written Ethics Policies to Business Decision-making," SAM Advanced Management Journal, (No. 59, 1994), 3239.

15. Keeley, M., A Social-Contract Theory of Organizations, University of Notre Dame Press, Notre Dame, IN, 1988.

16. Kurtz, D, L., Commentary On Social Responsibility and the Marketing Educator: A Discussion Document, Journal of Business Ethics, 19 (April, 1999), 207-209.

17. Lawrence, F. G., "Whose Ethics Guide Business?," Management Review, 65 (No. 4, 1976), 44-48

18. Malhotra, N. \& G. L. Miller., "Social Responsibility and the Marketing Educator: Focus on Stakeholders, Ethical Theories, and Related Codes of Ethics," Journal of Business Ethics, 19 (April, 1999), 211-224.

19. Manning, K.C., W. O. Bearden, \& T. J. Madden, "Consumer Innovativeness and the Adoption Process' "Journal of Consumer Psychology, 4 (No. 2, 1995), 329 - 345. 
20. Mason, J. B, W. O. Bearden, and L. D. Richardson, "Perceived Conduct and Professional Ethics Among Marketing Faculty," Journal of the Academy of Marketing Science, 18 (Summer, 1990), 185-197.

21. McDonald, B. \& N. Nijhof, "Beyond Codes of Ethics: An Integrated Framework for Stimulating Morally Responsible Behavior in Organizations," Leadership \& Organization Development Journal, 20 (No. 2, 1999), 133-146.

22. Nixon, J. C., C. Wiley, \& J. F. West, "Ways to Encourage Ethical Conduct Among Marketing Professionals," European Business Review, 92 (No. 2, 1992), 19-21.

23. Obermiller, C \& E. R. Spangenberg, "Development of a Scale to Measure Consumer Skepticism Toward Advertising," Journal of Consumer Psychology, 7 (No. 2, 1998), 159-186.

24. Pajo, K. \& P. McGhee, "The Institutionalization of Business Ethics: Are New Zealand Organizations Doing Enough?," Journal of the Australian and New Zealand Academy of Management, 9 (No. 1, 2003), 52-65.

25. Saxe, R.\& B. A. Weitz, "The SOCO Scale: A Measure of the Customer Orientation of Salespeople," Journal of Marketing Research, 19 (August 1982), 343-351.

26. Sharma, S., R. Netemeyer, \& V. Mahajan, "In Search of Excellence Revisited: An Empirical Investigation of Peters and Waterman's Attributes of Excellence," In: Enhancing Knowledge Development in Marketing, (No. 1, 1990), 322-328, (Edited by W. O. Bearden and A. Parasuraman, American Marketing Association, Chicago, IL).

27. Sherrell, D. L., J. F. Hair, Jr., \& M. Griffin, “Marketing Academicians' Perceptions of Ethical Research Behavior," Journal of the Academy of Marketing Science, 17 (Fall 1989), 315-324.

28. Sirgy, M.J., "Social Responsibility and the Marketing Educator: A Discussion Document," Journal of Business Ethics, 19 (April 1999), 193-206.

29. Sirgy, J. M., P. H. Siegel, \& J. S. Johar, J. S., "Toward a Code of Ethics for Accounting Educators', Journal of Business Ethics, 61(No. 3, 2005), 214-234.

30. Slama, M.E. \& A. Tashchian, A., "Selected Socioeconomic and Demographic Characteristics Associated with Purchasing Involvement,', Journal of Marketing, 49 (Winter 1985), 72- 82.

31. Soule, E., "Managerial Moral Strategies - "In Search of a Few Good Principles," Academy of Management Review, 27 (January 2002), 114-124.

32. Soutar, G.M., M. M. McNeil, \& C. Molster, "The Impact of the Work Environment on Ethical Decision Making: Some Australian Evidence,” Journal of Business Ethics, 13, 1994, 327-339.

33. Stead, W. E., D. L. Worrell, \& J. G. Stead., “An Integrative Model for Understanding and Managing Ethical Behavior in Business Organizations," Journal of Business Ethics, 9 (No. 3, 1990), 223-242.

34. Trevino, L.K., G. R. Weaver, D. G. Gibson, \& B. L. Toffler, "Managing Ethics and Legal Compliance: What Works and What Hurts," California Management Review, 41, 1999, 131-151.

35. Wiley, C., "The ABC's of Business Ethics: Definitions, Philosophies and Implementation," Industrial Management, 37, 1995, 22-21. 
NOTES 